Quarterly Journal of the Geological Society

\title{
Description of Anthracosaurus Russelli, a new Labyrinthodont from the Lanarkshire Coal-field
}

T. H. Huxley

Quarterly Journal of the Geological Society 1863, v.19; p56-68.

doi: 10.1144/GSL.JGS.1863.019.01-02.11

\section{Email alerting service}

Permission request

Subscribe click here to receive free e-mail alerts when new articles cite this article

click here to seek permission to re-use all or part of this article

click here to subscribe to Quarterly Journal of the Geological Society or the Lyell Collection

\section{Notes}


from ammonia, which is sometimes introduced into fossils by infiltration. A want of sufficient material prevented fuller investigations of the organic elements in these remains.

The fossil bones hitherto analysed appear to have been all from the more recent formations; but it was remarked that the results of this analysis of a Palæozoic fossil did not differ materially, in most respects, from those previously obtained by analysing fossil bones from much newer deposits.

2. Description of Anthracosaurds Russelli, a new LabyrinthoDont from the Lanarishire Coal-Field. By T. H. Huxley, Esq., F.R.S., F.G.S., Professor of Natural History in the Royal School of Mines.

Is September last, Mr. James Russell, Mineral Surreyor, of Chapelhall, near Airdrie, called at the Museum of Practical Geology to make some inquiries respecting the probable nature of a fossil (supposed to be a fish) lately brought to light by the workmen engaged upon the Monkland Iron and Steel Company's estate, about a mile from Airdrie and twelve miles east of Glasgow, and found in what is known as the Airdrie or Mushet's black-band Ironstone*. I was at that time absent from London; but Mr. Etheridge, to whom Mr. Russell described the fossil, strongly advised that a careful drawing should be made and sent up to London, for my examination. This was eventually done, and the sketch, faithfully executed in its general characters, which reached me on the 6th of November, appeared so conclusively to indicate the Labyrinthodont nature of the fossil, that I at once requested Mr. Russell to permit me to have it sent up to the Museum for closer examination. Mr. Russell very obligingly consented to this proposition, and the specimen reached me in perfect safety on the 27th of November, my interest in it having in the meanwhile been greatly heightened by the reports respecting its characters which had reached me from Professor Rogers, Mr. David Page, and Mr. Armstrong of Glasgow.

A glance at the fossil was sufficient to satisfy me that these reports had not unduly exaggerated its merits. It exhibited, in fact, the greater part of the contour of a skull, 15 inches long by 12 inches wide at the widest part. That the under or palatine surface of the skull was turned towards the eye was obvious from the numerous stumps of broken teeth which followed the anterior moiety of its contour;

* The President has kindly furnished me with the following note respecting the stratigraphical position of the Airdrie black-band Ironstone:-

"The fossils described in this memoir were found in, or else close to the "Airdrie or Mushet's black-band' Ironstone, which at this point changes into Coal. According to Mr. Ralph Moore's published section, this stratum lies about 564 feet below the topmost Coal-measures, and about 666 feet above the 'Moorstone rock,' which I believe to be the general equivalent of the English Millstone grit. The bones were therefore found in the true Coal-measures, far above the Gilmerton Limestone series (the equivalent of part of the English Carboniferous limestone, in which Loxomma was discovered), and probably 2000 feet or more above the horizon of the Burdie House limestone." 
but almost the whole of this surface was obscured by a thick coat of the matrix, in which were partially imbedded many of the long and pointed crowns of the teeth. These had been broken off, and lay not very distant from their stumps, with their points all directed inwards, towards the middle line of the palate. Their arrangement was just such as might have been expected if the axes of the teeth had naturally been turned somewhat inwards, and the vertical crush of the superincumbent strata, after the fossilization of the skull, had consequently caused them all to fall inwards as they broke. The same pressure has produced a slight asymmetry of the whole skull.

From the proportional size and structural features of the teeth, and from the general contour of the skull, I concluded this to be a new genus of Labyrinthodonts ; but in order to make sure of the point, I proceeded to develope the fossil, from the hard matrix in which it was imbedded, with much care; removing some of the teeth and, on one side, even a portion of the bony palate, in order to obtain a view of those parts, such as the orbits and posterior nares, which would enable me to decide the question.

The skull, as it now appears (fig. 1), presents almost the whole of its palatine or inferior surface to view, with the exception of the right temporal region. Its greatest length, measured along a median line drawn from the middle of the premaxillary region to a level with the posterior and external points of its prolonged and broad temporal prolongations, is 15 inches. Its greatest width, obtained by doubling the distance from the left posterior and outer margin to the middle line, is 12 inches. Opposite the great vomerine tusks $(d)$, the skull measures $5 \cdot 3$ inches in width. It diminishes slightly from this point to the rounded snout, and gradually increases in breadth posteriorly to the level of the supratemporal foramina $(c)$, where it measures about 10 inches in width. Beyond this point it widens suddenly by about half an inch on each side, and the lateral contours continue to diverge from hence to a point about $2 \frac{1}{2}$ inches distant from the hinder extremity of the temporal prolongations of the skull. The external contour of the temporal prolongation now becomes rounded off, and sweeps evenly inwards, until it meets the internal contour, which appears to be nearly straight. The epiotic processes are not visible.

In the middle line of the base of the skull, extending as far backward as the level of the posterior part of the supratemporal foramen, is the well-ossified basisphenoid, 1.7 inch broad, and slightly excavated posteriorly. The basisphenoid narrows anteriorly, so that, at 1.4 inch from its posterior extremity, it is not more than 0.9 inch wide; beyond this point it suddenly widens to form the lateral processes, like those commonly exhibited by the basisphenoid of fishes, and then rapidly tapers forward, having, at 2.8 inches from its hinder extremity, a diameter of not more than 0.25 inch, and continuing straight and style-like as far as it can be traced, which is to a distance of about 6 inches from its hinder extremity.

The limits of the vomers cannot be accurately defined; but they 
are very broad plates, separating the large anterior palatine foramina $(a)$ from the comparatively small posterior nares $(b)$, which are round apertures, 1 inch in diameter, and 5 inches from the anterior end of the snout, situated between the vomer, the maxilla, and the palatine bones on each side. The vomers unite in the middle line with one another and with the prolonged anterior extremity of the basisphenoid. Posteriorly they are connected with the palato-pterygoid arcade, the separate components of which cannot be accurately defined. The palatine portion, however, is a broad, flat plate, measuring 3.5 inches between the posterior nares and the palato-temporal foramen. It is united externally with the maxilla. Internally it is separated by a narrow interval from the basisphenoid. Posteriorly it passes into the pterygoid portion, which is narrow and curves outward, beneath the inner contour of the temporal prolongation of the skull, to be lost about the posterior and internal angle of that region. Externally the margin of the pterygoid portion is arcuated, to form the boundary of the palato-temporal foramen. Through this foramen the under surface of the upper wall of the skull in the temporal region becomes visible. The sutures separating the component bones of this region are not visible ; but on the level of the posterior end of the basisphenoid it presents an elongated aperture, or supratemporal foramen (c), 1.3 inch long by 0.4 inch wide. The long axis of this foramen is directed obliquely forwards and inwards, and it is nearer the pterygoid than the external boundary of the palato-temporal foramen.

Although I worked out this region of the skull with extreme care, I was in doubt whether the aperture in question was really a natural one, until I cleared away the matrix from the opposite side, and there found a foramen of quite a similar character, though distorted by the crushing of this part of the skull.

The premaxillary bones, strong and arched, send back two processes from their apposed ends, which run upwards and backwards in the middle line (in the manner common in Amphibia) towards the junction of the vomers. As the anterior portion of the vomerine plate is inclined upwards and forwards, it follows that the most anterior region of the palate has a somewhat arched roof, as in the Frog. The anterior palatine foramina $(a)$, included between the recurrent processes of the premaxillaries, their dentigerous processes, and the vomers, appear to be about $1 \frac{1}{2}$ inch long by 1 inch wide; but it is difficult, from the condition of the fossil, to define their limits with exactitude.

Thirty-seven teeth, or remains of teeth, are visible. Of these, on the left side, thirteen are situated in the premaxilla and maxilla, and three on the palatine bone; while, on the right side, nineteen are attached to the premaxilla and maxilla, one to the vomer, and one to the palatine bone. On the whole, the maxillary teeth decrease in size from before backwards, but not very regularly. The first tooth on the left side was 1.7 inch long when entire, by about half an inch thick at the base. The second immediately follows it, and is somewhat larger. The third, of about the same size as the second, 
Fig. 1.- Palatine aspect of the skull of Anthracosaurus Russelli. (One-third of the natural size.)

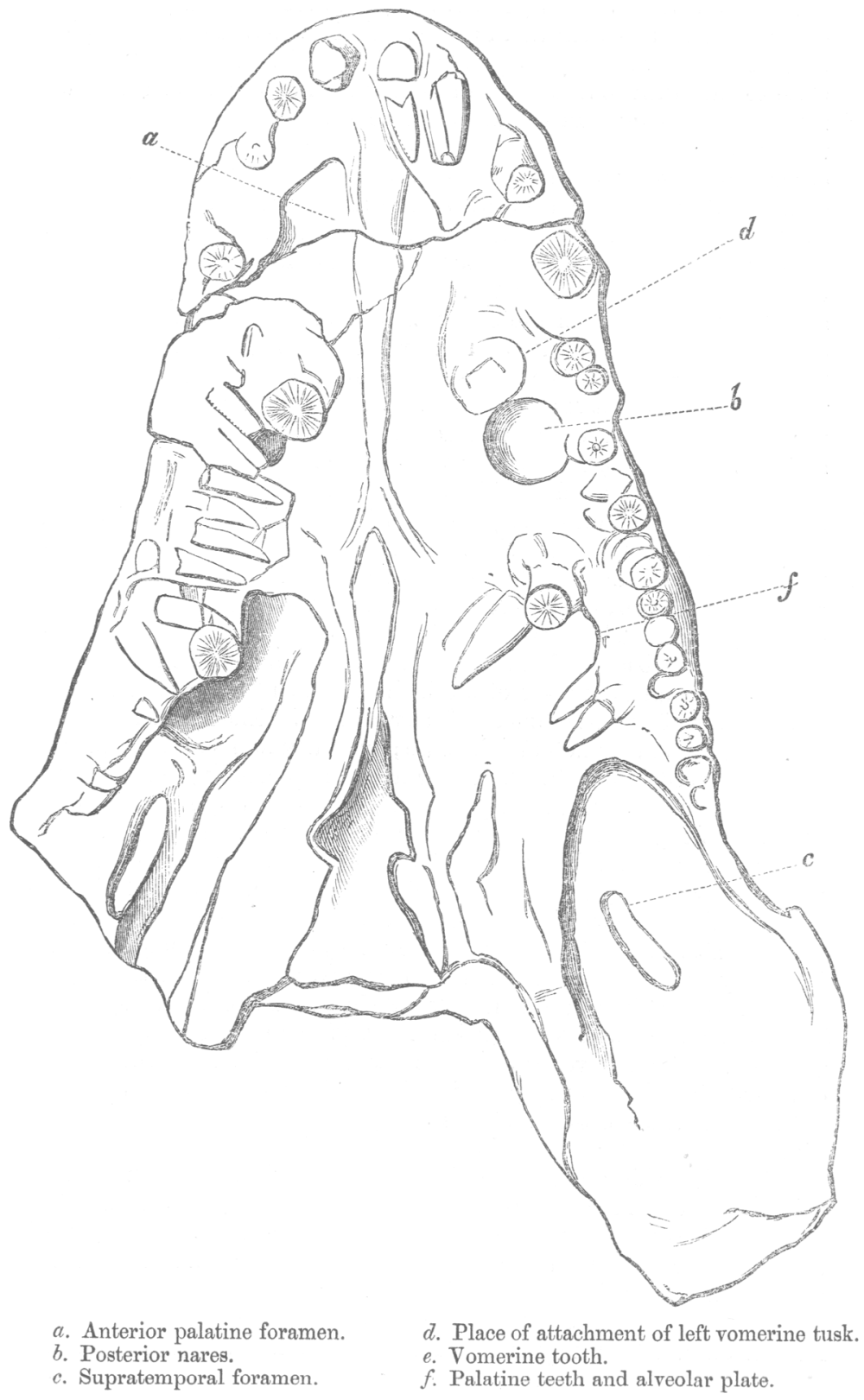


is separated from the latter and from the fourth, by spaces about three-quarters of an inch wide. The fourth tooth, broken short off, must have been a very large one, being not less than three-fourths of an inch in diameter at the base. It is separated by a deepish fossa, 0.7 inch wide, from the succeeding tooth. This, the fifth, is close to the sixth, and both are small, the base of neither attaining more than 0.3 inch in diameter. The seventh and eighth teeth, rather large, are situated at tolerably equal intervals from one another, and from their predecessors and successors, in the interspace of about 2 inches which separates the sixth from the ninth tooth. There are marked fossæ, as if for the reception of the points of mandibular teeth, between them. The bases of the ninth and tenth teeth, close together, occupy 0.7 inch. They are separated by a space of about half an inch from the eleventh tooth, and this by a somewhat smaller interval from the twelfth, which is close to the thirteenth. The bases of these last-mentioned teeth do not exceed 0.4 inch in diameter. The last tooth is nearly on a level with the anterior margin of the palato-temporal foramen. There is a fossa of nearly the same size as its base behind it, but no trace of the attachment of any other tooth.

The premaxillary and maxillary teeth on the right side by no means exactly correspond, either in position or in size, with those on the left.

The tooth nearest the middle line in the right premaxilla is sixtenths of an inch in diameter, and its base and its several fragments, when put together, show that it had a length of at least an inch and three-quarters. The two succeeding teeth are about half an inch in diameter at the base, and are not more than a quarter of an inch apart. Then follows an interspace of 0.9 inch, in which $I$ think $I$ can trace the remains of the attachment of a great tusk. Then comes a large tooth, 0.7 inch in diameter at the base; and then four small ones, none of which exceed 0.3 inch. The crowns of the succeeding teeth are all broken off, and lie with their points inwards upon the matrix, which covers this region and obscures their broken roots. None of them, however, have a basal diameter of more than 0.35 inch, and the last measures hardly more than 0.2 inch at the base. The anterior of these teeth are about 1.3 inch in length, while the hinder ones become shorter, until the last was probably not more than half an inch long when entire. The right vomer gives attachment to an immense tusk, 0.8 inch in diameter at the base. It could hardly have been much less than 3 inches long, but it is unfortunately broken short off. The left vomer presents the surface for the attachment of a similar tusk, but the tooth itself is entirely detached. There is not the least trace of the existence of any other vomerine teeth besides these.

On the left side, the palatine bone, eight-tenths of an inch behind the posterior nasal aperture, supports a tusk 0.6 inch wide at the base, which, when entire, was very nearly 2 inches long. The palatine bone is raised up into a ridge, so as to form a sort of alveolar wall on the outer side of this tusk, and the wall is continued backwards as a thin plate of bone directed almost horizontally inwards $(f)$. At a distance of three-quarters of an inch from the great anterior 
tusk, the alveolar plate, the margin of which is excavated in the interval, affords support to a tooth 0.35 inch in diameter at its base, and this is immediately followed by another of the same dimensions. These teeth are about 0.9 inch long.

On the right side, the base of a similar palatine tusk and part of an alveolar plate are visible; but there are no small teeth, and the tusk is situated nearly an inch further back than on the left side. But the alveolar plate extends forward in front of this tusk, and presents a deep sinus, in which I suppose a tusk corresponding to that on the opposite side may have been developed. If the sinus upon the palatine alveolar plate of the opposite side has the same signification, it would appear as if there were normally two great palatine tusks on each side, but that the anterior and posterior of opposite sides are shed simultaneously.

The fossil was broken into two pieces when it reached me; the fracture passing obliquely between the third and fourth teeth on the left side, and through the fourth on the right. The fractured surface shows the roof of the skull, or rather the snout, and proves that it was raised into a broad longitudinal ridge, so convex as to be almost semicircular, about 1.5 inch broad and 0.6 inch above the general level of the facial bones. From the sides of this convexity, the sides of the face slope with a gradual curve towards the alveolar margin. The depth of the skull, immediately over the centre of the maxillary alveoli, is rather less than one inch. From the centre of a line joining the margins of the alveoli to the top of the central ridge is a distance of about 1.9 inch; and in the occipital region the skull is not deeper : considering its breadth and length, therefore, the skull is extremely flat.

The teeth are round, or slightly oval in section at their bases, and throughout the greater part of their length. They taper gradually to sharp points and become slightly incurved towards their apices. Their bases are not grooved, but, on the contrary, are marked by numerous delicate and sharp longitudinal ridges, so that transverse sections appear to be very slightly polygonal. Towards the apex of the tooth, two of these ridges, an anterior and a posterior, become more distinctly marked, and, combined with a very slight flattening of the tooth, give it a double edge.

In one of the anterior teeth, the front face towards the point is much worn, as if by attrition against one of the mandibular teeth.

Transparent transverse sections of the teeth exhibit a singularly beautiful and complex structure. The relatively small pulp-cavity sends off primary radiating prolongations, which pass straight to the circumference of the tooth, and at a small distance from it terminate by dividing, usually, into two short branches, each of which gives off from its extremity a wedge-shaped pencil of coarse dentinal tubuli. These spread out from one another, and terminate in a structureless or granular layer, which forms the peripheral portion of the dentine, and, from the small irregular cavities scattered here and there through its substance, reminds one of the 'globular dentine' of the human tooth. An extension of this peripheral layer is continued 
towards the centre of the tooth, between every pair of primary prolongations of the pulp-cavity. The short secondary processes which are sent out from opposite sides of the primary prolongations of the pulp-cavity, give off in the same way, from their ends, pencils of conspicuous dentinal tubuli, the ends of which terminate in the inward extensions of the peripheral layer. The secondary processes of adjacent primary prolongations alternate and, as it were, interlock with one another, so that the inward extension of the peripheral layer takes a sinuous course between them. A thin layer of dense and glassy enamel invests the tooth continuously, but sends no processes into its interior; and, of course, under these circumstances there can be no cement in the interior of the tooth, nor can its surface be said to be plaited or folded. It will be understood that this description gives merely the principle of arrangement of the parts of the tooth : its details could only be made intelligible by elaborate figures.

In Rhizodus and in Ichthyosaurus the principle of construction of the complex tooth is totally different, the surface of the tooth being really folded, and prolongations of the cement being continued into the folds.

\section{Addendum, January 14, 1863.}

The Referee, to whom the preceding description of the skull of Anthracosaurus was sent, has suggested that it is desirable I should express some opinion respecting the systematic relations and affinities of the fossil. I am glad that I am in a far better position to comply with this suggestion now, than I was when the description of the cranium was sent to the Society; for at that time $I$ was not in possession of the valuable evidence regarding the characters of the vertebral column, which has come into my hands within the last few days through the exertions of my indefatigable correspondent, Mr. Russell.

For some years past, I have been acquainted with well-ossified vertebræ and ribs from the Carboniferous formation; but the vertebræ have always been devoid of their arches and processes; and though the ribs presented characters suggestive of their belonging to a higher division of the Vertebrata than Fishes, I thought it better to wait for further evidence as to their real nature before giving any account of them.

More than a year ago, I brought away with me from the collection of the Earl of Enniskillen, at Florence Court, a remarkable rib and vertebral centrum. I have seen similar remains in the admirable collection of Dr. Rankin, of Carluke ; and, more recently, Mr. Russell has sent me up a number of vertebral bodies of different kinds from the Airdrie workings. I had every reason to believe some of these vertebræ to belong to Anthracosaurus, and it was with that conviction in my mind that I ventured to caution the members of the Geological Society, on the occasion of the reading of Mr. Marsh's paper on " Eosaurus Acadianus," * against too hastily concluding that the vertebral centra, which he had found in the Nova-Scotian coal-

$$
\text { * See antè, p. } 52 .
$$


field and then described, were necessarily Ichthyosaurian,--seeing that I had much reason to suspect that they might belong either to Labyrinthodonts, or to some genus of intermediate characters, between Labyrinthodonts and Ichthyosaurians.

Within the last few days Mr. Russell has sent me the vertebra of which an outline-view is given in fig. 2 (one-half the natural size). It was found in the same bed as that which yielded the skull of Anthracosaurus, and corresponds very well in size with what one might expect would be the dimensions of a dorsal vertebra of that animal. Associated with it on the same slab are several other less complete vertebræ and the remains of two ribs.

Fig. 2.

A. Dorsal vertebra of Anthracosaurus, viewed from behind.

B. Rib of the same Amphibian.

A.
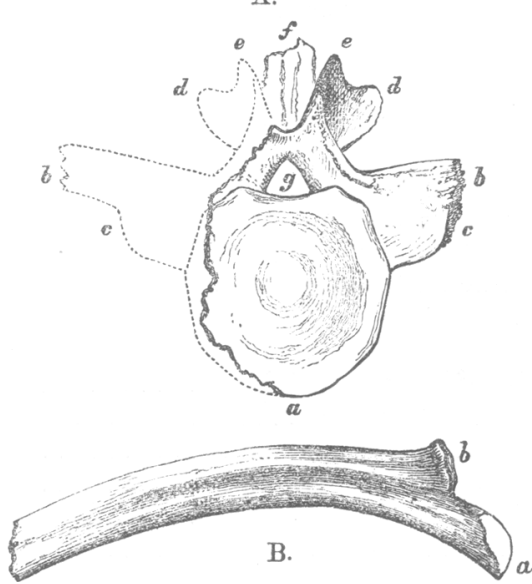

A.- a. Body of the vertebra.

b. The longer division of the transverse process, and

c. The shorter division.

d. Anterior zygapophysis.

e. Posterior zygapophysis.

B. - a. Capitulum. b. Tuberculum.

The body of the vertebra is greatly flattened from before backwards, as the subjoined measurements will show. The exposed articular surface is concave, and a section which $I$ have had made of a similar vertebral body shows that it was equally concave upon both sides. The concavity, however, is not conical in section like that of a fish's vertebra, but its sides are a little convex, rising slightly, within the margin. Hence the section of this vertebra has very much the same appearance as that of Mr. Marsh's problematical vertebra represented in the figure which accompanies his paper*.

The contour of the vertebral body is not circular, but is slightly angulated, so that it would tend to be octagonal were not the place of

* Am. Journ. Science, n. s., vol. xxxiv. pl. 2. fig. 2. 
the uppermost angle of the octagon occupied by the excavated floor of the neural canal. The short sides of the vertebral body are concave from before backwards, and in other specimens exhibit a slightly rugose marking.

The neural arch is very small in proportion to the size of the body of the vertebra, and its contour is nearly that of an equilateral triangle with a curved base.

The very stout sides of the neural arch are continued upwards into a strong spinous process, which is broken off a short distance above its origin and nearly on a level with the upper parts of the zygapophyses. Of the latter the posterior pair are turned towards the eye, and are much broken. The hinder face of the right anterior zygapophysis is visible (at $d$ ), and its curved contour is nearly entire.

The transverse process of the right side (the only one preserved) springs by a long line of origin from the lower part of the neural arch and from the upper half of the circumference of the vertebral body. It is greatly flattened from before backwards, and its lower half (c) ends, at a distance nearly equal to half the diameter of the body of the vertebra, in a rounded edge, which appears to be complete and unbroken. The upper half, on the other hand, terminates in an obviously rough and fractured extremity. I conclude from this circumstance, and from the characters exhibited by the proximal ends of the ribs, which I shall immediately describe, that the upper division of the transverse process extended much further outward than the lower, and $I$ have indicated this in the dotted restoration of the left side of the vertebra.

$\begin{array}{llll} & & & \text { inch. } \\ \text { Height of body of vertebra } & \ldots \ldots \ldots \ldots & 1.6 \\ \text { Transverse diameter } \ldots \ldots \ldots \ldots \ldots \ldots \ldots & 1.6 \\ \text { Length } \ldots \ldots \ldots \ldots \ldots \ldots \ldots & \ldots \ldots \ldots \ldots \ldots & 0.47 \\ \text { Height of neural arch } \ldots \ldots \ldots \ldots \ldots \ldots & 0.3 \\ \text { Depth of transverse process } \ldots \ldots \ldots \ldots \ldots & 0.8 \\ \text { Thickness of transverse process } \ldots \ldots \ldots \ldots & 0.6\end{array}$

The best-preserved rib is $6 \frac{1}{2}$ inches long* and half an inch broad, measured in a direction perpendicular to its length. It is, however, much flattened from before backwards, so that its thickness does not amount to more than one-sixth of an inch. The face of the rib is not flat, but it is somewhat excavated, so that the bone is thinner in the middle than at the edges. At its proximal end the rib exhibits a very distinct tuberculum and capitulum. The former projects, so as to disturb the sweep of the curve of the convex side of the rib and to convert it for a short distance into a concavity, and it is abruptly truncated posteriorly. The capitulum of the rib continues the line of its general curvature for half an inch beyond the tuberculum, and ends in a rounded extremity. I presume that the capitulum articulated with the lower half of the transverse process $(c)$, and that the tuberculum articu-

* The sternal end of the rib is broken off. It was certainly much longer when perfect, as the rib from Lord Enniskillen's collection, though more slender, measures $8 \frac{1}{2}$ inches along its curve, and still presents a fractured extremity. 
lated with its upper half, in which case the distance $(a, b)$ on the rib would be practically equal to the excess of length of the upper division of the transverse process over that of the lower.

The skull, a dorsal vertebra, and a rib of Anthracosaurus being known, I now return to the question, what are the affinities of that Labyrinthodont?

The large size of the teeth, the comparative solidity of their bases, and the complex character of the labyrinthic ramifications of the pulpcavity are all characters in which Anthracosaurus resembles the Mastodonsaurus of von Meyer and Plieninger and its allies, and differs from Archegosaurus. Whether Anthracosaurus had well-ossified occipital condyles like Mastodonsaurus, or cartilaginous ones such as were probably possessed by Archegosaurus, does not appear, the fossil being defective in this region. In the large size of the anterior palatine foramina, the extent to which the palate-bones are united with the maxillaries, in the form of the pterygoidean arch and that of the basisphenoid, Anthracosaurus is nearer to Archegosaurus and Dasyceps than to Mastodonsaurus.

But the vertebræ are altogether Mastodonsaurian. The vertebræ of Mastodonsaurus were described and figured in 1844 in the wellknown work of von Meyer and Plieninger, 'Beiträge zur Paläontologie Würtembergs.' No fewer than seventeen vertebræ were discovered in one slab, together with the skull of this remarkable Labyrinthodont; another block contained eight vertebræ, belonging to the same animal, but not immediately succeeding the former; and a third slab of stone contained five more trunk-vertebræ, besides three others which were caudal. Dr. Plieninger seems inclined to think that all these cervico-dorsal vertebræ belonged to one animal: but even the fact that seventeen vertebræ were found together in one block, and the existence of caudal vertebræ, must be amply sufficient to satisfy every anatomist of the untenability of the hypothesis that the Labyrinthodonts were frog-like or toad-like in form.

The trunk-vertebræ of Mastodonsaurus are biconcave, and much flattened from before backwards. The neural arch ends above in a strong spinous process; there are well-developed zygapophyses, and the stout transverse processes exhibit a division into an upper longer and a lower shorter portion. So far they are very similar to those of Anthracosaurus. The ribs again are strikingly similar to those of Anthracosaurus, as may be seen by comparing plate 5. figs. 1 \& 2 of the work cited with fig. $2, \mathrm{~B}$.

On the other hand, the vertebræ of Mastodonsaumu, according to Plieninger, presented characters which I do not meet with in $A n-$ thracosaurus. Thus, the articular surfaces of the bodies of the vertebræ of the Triassic Amphibian are inclined towards one another superiorly, while those of Anthracosaurus are parallel ; and the upper and lower portions of the transverse process, which are said by Plieninger to be separated by a suture, so that the neural arch, with the upper longer transverse processes, readily separates itself from the body with the lower and shorter transverse processes, are, so far as I can observe, perfectly continuous in the Carboniferous Amphibian.

VOL. XIX.-PART $\mathrm{T}$. 
Double transverse processes, the upper more particularly connected with the neural arch, and the lower with the body of the vertebra, are to be found, though the circumstance does not seem to have received much notice from palæontologists, in several genera of Saurobatrachia, or Salamandroid Amphibians.

In Salamandra maculosa, for example, each cervico-dorsal vertebra, except the atlas, has, on each rib, a prominent transverse process inclined backwards ; and all these processes, except perhaps the very last, are deeply bifid, so as to be divided down nearly to their origin into two more or less divergent processes. The upper division comes off distinctly from the neural arch, while the lower arises for the most part below the level of the upper margin of the articular face of the body of the vertebra. The transverse processes of the three or four anterior caudal vertebræ are also bifurcated at their ends, and at the eighth or ninth caudal the transverse processes cease to be distinguishable.

The proximal ends of the four anterior pairs of ribs are divided into capitular and tubercular processes of nearly equal length, and possess a distinct 'angle,' whence a process is given off upwards and outwards*. In the hinder ribs the tuberculum becomes a little shorter and more slender than the capitulum. In Pleurodeles Waltlii, the vertebral column and the proximal ends of the ribs resemble those of Salamandra maculosa, though the division of the transverse processes is less marked, and the capitulum and the tuberculum of the ribs are not so deeply separated; indeed, posteriorly, the separating cleft becomes almost obsolete. In Enproctes the division of the transverse processes is hardly discernible ; nevertheless there is a rudiment of the angular processes in the anterior ribs. In other Saurobatrachia, a groove on each side, indicating an incipient division of the proximal end of the rib, is not uncommon. In all these cases, I am not aware that the single or bifid character of the transverse processes is correlated with any notable differences in other parts of the organization.

It appears to me, then, that the characters of the certainly Labyrinthodont vertebret made known by von Meyer and Plieninger, and in the present paper, are in perfect accordance with the view originally put forward by Professor Owen, that these animals are more closely allied to the Batrachia than to any of the Reptilia proper. But I conceive that the affinities of the Labyrinthodonts are clearly with the Saurobatrachia (and, in some cranial characters, with the Caciliaz), and not with the Anura as was at first suggested; and, with every deference to the opinion of so great an authority on all that relates to the Labyrinthodonts as von Meyer, I must venture to doubt whether, in any characters, these Amphibia exhibit a real approximation to the Reptilia.

* Plieninger notes what appears to be a process of a similar character to this in the ribs of Mastodonsaurus.

+ It does not appear that there is any evidence to show that the vertebre ascribed to Labyrinthodon by Professor Owen in his paper on the Warwickshire Labyrinthodonts (Geol. Trans. 1841) are such, while there is much reason to believe they are not. 
At present we are acquainted with two apparently very distinct types among the Labyrinthodonts-that of the ARchegosadria ( $\mathrm{Ar}$ chegosaurus), at present known to occur only in theCarboniferous rocks, and that of the Mastodonsadria (Mastodonsaurus, Labyrinthodon, Capitosaurus, Trematosaurus), which seem to have flourished in remarkable abundance during the Triassic epoch. Both groups exhibit the sculptured and polished* surface of the crania, the vomerine and palatine teeth, the forwardly situated posterior nares, the permanently distinct epiotic bones, the divided supra-occipital, the three sculptured pectoral plates, the elongated, caudate, salamandroid body, and the comparatively short limbs and weak feet which are distinctive features of the Labyrinthodont Amphibia, as well as the more or less complex ramifications of the pulp-cavities of the teeth, which they share with Fishes and Ichthyosauria.

But the Archegosauria have imperfectly ossified vertebral bodies $\downarrow$, while the Mastodonsauria have them thoroughly well ossified, though still biconcave ; and the Mastodonsauria have double ossified occipital condyles, which have not been found in Archegosauria.

Of the other distinctions, if such there were, of the two groups, we know very little. It is true that the Archegosauria had, as von Meyer has proved, in his splendid monograph 'Die Reptilien des Steinkohls,'a persistent branchial apparatus and a very remarkable scaly ventral armature. But what do we know with certainty about the presence or absence of corresponding structures in the Triassic Mastodonsauria? Whatever may be the nature of the doubtful Anisopus or Rhombopholis, it is certain that the African, probably Triassic, Micropholis was protected by ventral scutes ; and until Mastodonsaurian Labyrinthodonts are found preserved as favourably as the Archegosauria have been, I think it will be hazardous to take it for granted that they had neither ventral scutes nor even persistent branchial arches.

If we adopt these two divisions and endeavour to range the known Carboniferous Labyrinthodonts under one or the other,-Archegosaurus, of course, takes its place among the Archegosauria; and Pholidogaster $\mp$, I suspect, must go with it, though its vertebræ are far better ossified, and the condition of the cranial condyles is not known. Baphetes and Parabatrachus are too little known to justify us in arriving at any conclusion respecting them; and the like is true of Loxomma. As regards the Raniceps of Wyman (Am. Journ. of Sci. and Arts, 1858), the Dendrerpeton and Hylonomus recently discovered by Dr. Dawson in the Nova-Scotian coal-field, and the new genus Hylerpeton instituted by Professor Owen, from the same locality, I do not think we are even in a position to say that they are Labyrinthodont, much less whether they have Archegosaurian or Masto-

* Whence the term 'Ganocephala' as a distinctive appellation of the Archegosauria is inadmissible.

t It seems to me probable that the vertebral centra of Archegoscurus may really have been osseous rings, such as are found in embryo frogs and salamanders, and as persisted in Megalichthys and probably in Rhizodus, and that they have broken into the separate pieces described by von Meyer in the process of fossilization.

$\ddagger$ Quart. Journ. Geol. Soc. 1862. 
donsaurian affinities. Among the many remains discovered by the zealous research of Dr. Dawson, I do not know that a single specimen of one of the pectoral plates, so characteristic of all Labyrinthodonts, has made its appearance. They may possibly have been Amphibia; but their skulls, their cycloid scales, and their deeply biconcave, fish-like, vertebral centra appear to me to indicate a closer affinity with the Ophiomorpha (Coecilia, Ichthyophis, \&c.) than with the Labyrinthodontia.

Of the unquestionable Labyrinthodonts which occur in the Carboniferous rocks, then, Anthracosaurus is the only genus regarding the vertebral column and ribs of which there is any information; and the description and comparisons which I have given seem to me to necessitate the conclusion that, side by side with the Archegosaurian type, the Mastodonsaurian type of vertebral organization, hitherto known to occur only in the Trias*, was well developed in the $A n$ thracosaurus of the Scotch coal-field. At the same time, the anchylosed condition of the neural arches, the supratemporal foramina (which may, however, be parts of the 'mucous grooves' common upon Labyrinthodont skulls, the floor. of which was very thin, or merely membranous in the temporal region of Anthracosaurus), and the strong median convexity of the snout, separate Anthracosaurus from any known Triassic Labyrinthodont. And though, in the general form of the cranium and in some other respects, Anthracosaurus has a certain resemblance to the Permian Dasyceps, it differs as widely as possible from it in its dentition.

3. On the Thickness of the Pampean Formation, near Buenos Arres. By Charles Darwin, Esq., M.A., F.R.S., F.G.S., \&c.

M. Sourdeadx and J. Coghlan, Esq., C.E., have had the kindness to send me, through E. B. Webb, Esq., C.E., some excellent sections of, and specimens from, two artesian wells lately made at Buenos Ayres. I beg permission to present these specimens to the Geological Society, as they would be of considerable service to any one investigating the geology of that country. The Pampean formation is in several respects so interesting, from containing an extraordinary number of the remains of various extinct Mammifers, such as Megatherium, Mylodon, Mastodon, Toxodon, \&c., and from its great extent, stretching in a north and south line for at least 750 geographical miles, and covering an area fully equal to that of France, that, as it appears to me, a record ought to be preserved of these borings. Southward, at the Rio Colorado, the Pampean formation meets the great Tertiary formation of Patagonia; and northward, at Sta. Fé Bajada, it overlies this same formation with its several extinct shells.

In the central region near Buenos Ayres no natural section shows its thickness ; but, by the borings there made in two artesian wells (figs. $1 \& 2$ ), the Pampean mud, with Tosca-rock, is seen to extend

* Nothing is at present known of the vertebræ of Dasyceps Buck!andi, from the Bunter sandstein of this country. See Memoirs of the Geological Survey of Great Britain :-The Geology of the Warwickshire Coal-field ; by H. H. Howell, F.G.S. 1859 . 